\title{
The Heterogeneous State and Legal Pluralism in Mozambique
}

\section{Boaventura de Sousa Santos}

\begin{abstract}
This article analyzes some of the most salient features of the state and the legal system in Mozambique. I propose the concept of the heterogeneous state to highlight the breakdown of the modern equation between the unity of the state, on the one hand, and the unity of its legal and administrative operation, on the other. The centrality of legal pluralism is analyzed in light of an empirical research focused on community courts and traditional authorities. I use the concept of legal hybridization with the purpose of showing the porosity of the boundaries of the different legal orders and cultures in Mozambique and the deep cross-fertilizations or cross-contaminations among them. Special attention is given to the multicultural plurality resulting from the interaction between modern law and traditional law, the latter conceived here as an alternative modernity.
\end{abstract}

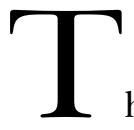

he end of the twentieth century witnessed a global call for the rule of law and the reform of judicial systems in many countries of the world. Multilateral financial agencies and international aid nongovernmental organizations (NGOs) made such changes one of their priorities for their efforts in the developing world. ${ }^{1}$ The global nature of this process and the intensity with which it was implemented, in both financial and political terms, reflected the rise of a new development model: the neoliberal development model. This model looks to a greater reliance on markets and the private sector and requires a new legal and judicial framework: only when the rule of law is widely accepted and effectively enforced are certainty and predictability guaranteed, transaction costs lowered,

This article was written in the ambit of the research project mentioned in the introduction. I would like to thank to all members of the research team: Andre Cristiano José, Conceição Gomes, Guilherme Mbilana, João Carlos Trindade, João Pedroso, Joaquim Fumo, Maria Manuel Marques, and Maria Paula Meneses. My very special thanks to João Carlos Trindade for sharing with me the coordination of the research project and to Maria Paula Meneses for the stimulating dialogues on African politics and culture and for her competent and diligent research assistance in the preparation of this article. Please address correspondence to Boaventura de Sousa Santos, Centro de Estudos Sociais, Apartado 3087,3001-401 Coimbra, Portugal; e-mail: bsantos@ces.uc.pt or bsantos@wisc.edu.

${ }^{1} \mathrm{I}$ analyze this phenomenon in great detail in Santos (2002:313-52). See also Tate and Vallinder (1995).

Law E Society Review, Volume 40, Number 1 (2006)

(C) 2006 by The Law and Society Association. All rights reserved. 
property rights clarified and protected, contractual obligations enforced, and regulations applied. In most countries across the developing world, profound legal and judicial reforms were implemented. They focused exclusively on the official legal and judicial system, conceived of as a unified system, and left out of consideration the multiplicity of unofficial legal orderings and dispute resolution mechanisms that had long coexisted with the official system, many dating back, in the case of Africa, to the colonial period. The neglect of nonstate legal structures, combined with the intense, globally induced call for reform and the changes in the role of the state, ended up widening the gap between the lawin-books and the law-in-action.

The focus of this article is the recent history and current nature of this gap in one African country: Mozambique. I focus on Africa because the disjunction between the officially established unity of the legal system and the sociological plurality and fragmentation of legal practice is probably more visible there than in any other region of the developing world. In the analysis that follows, I show that this disjunction has a multiple impact on state action and legitimacy, on the operation of the official legal system, on the relationships between political and administrative control, on the mechanisms of conflict resolution operating in society, on the legal and institutional frameworks of economic life, and on the social and cultural perceptions of politics and legality.

Mozambique is situated in southeast Africa, between South Africa and Tanzania. For several centuries a Portuguese colony, it became independent in 1975 . The revolutionary socialist development path adopted in the first decade after independence was abandoned in 1984 in the face of a deep economic crisis and under the pressure of multilateral financial institutions. It was replaced by a democratic capitalist development path that was later enshrined in the Constitution of 1990. At the end of the 1970s, a vicious civil war broke out, initially masterminded and fueled by the South African secret services. It ended 12 years later with the peace agreement of 1992, having left the countryside pulled apart and half a million dead. In 1987, the first structural adjustment agreement was signed. ${ }^{2}$ Considered one of the poorest peripheral countries, Mozambique was initially subjected to particularly harsh

${ }^{2}$ Structural adjustment programs (SAPs), designed by the International Monetary Fund (IMF) and the World Bank, have been the framework for economic and social policy in most developing countries since the early 1980s. SAPs - the general name for stabilization facilities and policy-based loans aimed at solving economic problems deemed to reflect deep-rooted structural weaknesses - have combined an IMF stabilization loan with conditionalities for longer-term economic and social policies overseen by both the World Bank and the IMF. The stabilization package, which addresses monetary and fiscal issues, typically attempts to address inflation and reduce the government's budget deficit and balance-of-payments problems. This is done with measures to reduce domestic demand, 
measures of restructuring, given its status as a "strong adjuster." It is today viewed as a "success story," having experienced in the last decade some economic recovery and having carried out the democratic transition with mixed results but without much turbulence.

The empirical research analyzed in this article was conducted between 1996 and 2002 as part of a much larger research project on the judicial system in Mozambique that I co-directed with João Carlos Trindade, a Supreme Court judge in Mozambique and director of the Center of Legal and Judicial Training of Maputo. ${ }^{3}$ The main results are available in Portuguese (Santos \& Trindade 2003). The empirical data more directly relevant for the analysis undertaken here comprise extensive research focused on 34 community courts and 23 traditional authorities, located in six of the country's 11 provinces (Maputo, Inhambane, Zambézia, Sofala, Tete, and Cabo Delgado). In-depth studies were conducted in five community courts - Mafalala and Xipamanine (in the city of Maputo), Liberdade (in Inhambane), Munhava Central (in Sofala), and Maimio (in Cabo Delgado) - and under six traditional authorities: the regulados Luis and Mafambisse (in Sofala), Cumbapo (in Zambézia), Zintambila (in Tete), and Cumbana and Nhampossa (in Inhambane). ${ }^{4}$ The data collection included direct observation of court sessions and dispute resolution settlements, archival data whenever available, and semi-structured interviews (60 community court judges, 23 traditional authorities, and 72 local leadersreligious leaders, presidents of community associations, members of grupos dinamizadores, local administrators, and police chiefswere interviewed). ${ }^{5}$

In "The Heterogeneous State and Legal Plurality," I deal very briefly with the recent transformations on the nature and role of

both government and private. Mozambique has been part of the IMF and the World Bank since 1984 .

3 The research was based at the Center for African Studies (CEA) of the University Eduardo Mondlane of Maputo and the Center for Social Studies (CES) of the University of Coimbra, Portugal. The research team was binational: João Carlos Trindade, Maria Paula Meneses, Andre Cristiano José, Guilherme Mbilana, and Joaquim Fumo of CEA, and this author, Maria Manuel Marques, Conceição Gomes, and João Pedroso of CES.

4 The régulo (chieftain) was institutionalized, in colonial times, as the lowest level of the administrative colonial system, working under the control of the local Portuguese administrators. The régulo's position is passed down from generation to generation, according to a hereditary system. Thus, where such a position still exists, its legitimacy derives from family lineages often going back to precolonial times. The régulo embodies different functions and powers that, in the language of modern politics, combine legislative, judicial, executive, and administrative dimensions.

5 The grupos dinamizadores were groups of eight to 10 people, chosen by a show of hands during the public meetings of urban neighborhoods, workplaces, or local rural communities throughout the country. They were revolutionary units entrusted with both political and administrative tasks. They reported to the Frelimo-appointed local administrators (Frelimo is the ruling political party). Popular vigilante groups were also formed to assist the grupos dinamizadores. 
the state in Africa and its impact on legal pluralism. In "A Palimpsest of Political and Legal Cultures," I analyze the social and political conditions that account for the heterogeneity of state action and legal pluralism in Mozambique. In "Entangled Legal Pluralities: The Community Courts as Legal Hybrids," I focus on the community courts, conceived as legal hybrids, and in "Multicultural and Multi-Ethnic Justices: The Case of the Traditional Authorities," on traditional authorities, conceived as alternative legal and political modernities.

\section{The Heterogeneous State and Legal Plurality}

\section{The Emergence of the Heterogeneous State}

The globalizing pressure Africa is experiencing today is perhaps more intensive and selective than ever before. Since the fifteenth century, Africa has been subjected to various forms of globalization originating in the West, including colonialism, slavery, imperialism, neocolonialism, and structural adjustment. The intensity of the most recent form of globalization lies in the fact that it is almost totally impossible to be resisted locally. It appears as an unconditional and ineluctable imperative. ${ }^{6}$

The impact of neoliberal globalization in Africa is most visible in the changing structures and practices of the state. The states that emerged from the processes of independence became in one way or another developmentalist states. Although huge differences existed between them-above all the difference between those that adopted the capitalist and those that adopted the socialist path toward development - the new states presented themselves as the driving forces of development. They were seen as the centers of strategic economic decisionmaking and as holding total primacy over civil society, a concept little used during the immediate afterindependence period. This model of the state operated through great bureaucratic apparatuses, many of which had been inherited from the colonial state. Moreover, this "overdimensioning" or "overdevelopment" of the state in relation to society constituted one of the most resistant forms of continuity with the colonial regime (Bayart 1993; Young 1994).

Between the mid-1970s and early 1980s, this model of the state entered into a crisis. It was during this transition period, in 1975 ,

${ }^{6}$ It is true that global pressures are subject to local adaptations, but these pressures, above all in peripheral countries, are less open to negotiation or else are marginal or dictated by the philanthropic whim of international agencies or core countries in particularly extreme situations of social collapse. A good illustration of this is the HIPIC initiative (Highly Indebted Poor Countries) led by the World Bank and creditor countries to alleviate the foreign debt of the most impoverished countries. 
that the countries freed from Portuguese colonialism-Mozambique, Angola, Guinea-Bissau, the Cape Verde Islands, and São Tomé and Príncipe - emerged, and all of them, without exception, adopted the socialist path to development. ${ }^{7}$ With the final collapse of the Soviet Union already imminent, the Washington Consensus, adopted by IMF and the World Bank under the aegis of the U.S. Department of the Treasury, in the mid-1980s, sealed the fate of nationalist and socialist models of development based on the primacy of the state. ${ }^{8}$ From then on, the state, which under the previous model of development had been the solution to the problems of society, became the great problem of society. Inherently predatory and inefficient, it had to be reduced to a minimum, since reducing its size was the only way of reducing its negative impact on the development of society-based problem-solving mechanisms.

In many African countries, the production of the weak state, combined with the socially devastating consequences of structural adjustment, led some states to the brink of total implosion. As always, external factors have combined with internal ones to create civil wars, interethnic wars, the rise of corruption, and, consequently, the privatization of the state and the collapse of its fragile administrative structures, above all in the area of education and health care policies and basic infrastructure. By the mid-1990s, the World Bank itself recognized that the new model of development presupposed a state strong and efficient enough to ensure an effective regulation of the economy and the stability of the expectations of economic agents and social actors in general. As latecomers, the new states that emerged from Portuguese colonialism in the mid-1970s, after decades of liberation struggles, suffered even more drastically the consequences of the new global impositions that affected in profound ways the most basic tasks of state-building. In "A Palimpsest of Political and Legal Cultures," I illustrate this with the case of Mozambique.

As a consequence of the global imperatives just mentioned, the African nation-state has lost centrality and dominance by the emer-

${ }^{7}$ Africa was the only continent not partitioned by the Treaty of Yalta at the end of World War II and therefore the one where the Cold War became a permanent "war of position," to use the Gramscian term. Portuguese colonialism survived for so long, despite its weakness as a colonial power, in part because it served the interests of the capitalist countries by functioning as a barricade against Soviet advances in Southern Africa. Still in the midst of the Cold War, the newly independent countries sided with the Soviet bloc, which was already showing visible signs of decline. The Soviet threat explained the war of destabilization waged by apartheid South Africa against Angola and Mozambique. The war of destabilization gave way to civil war, which lasted in Mozambique until 1992 and in Angola until 2002.

8 The Consensus argued that the keys to success in developing countries were macrostability, liberalization (lowering tariff barriers and market deregulation), and privatization. It was largely formulated from experience with Latin America. The term Washington Consensus was coined by Williamson (2000). 
gence of powerful suprastate political processes. However, in an apparently paradoxical way, these same processes have led to the emergence of infrastate actors (sometimes very powerful actors) equally determined, albeit for very different reasons, to question the centrality of the nation-state. A case in point is the reemergence of traditional authorities as a social and political actor, a phenomenon that, as I show below, occurred in Mozambique. These combined pressures have led to a double decentering of the state, at an infra- and a suprastate level. This does not mean that the state has ceased to be a key political factor. However, the ways in which the state is being contested and reformed transform it into an increasingly complex social field in which state and nonstate, local and transnational relations interact, merge, and confront each other in dynamic and even volatile combinations, making the nature of legal plurality ever more complex. The centrality of the state resides now, to a great extent, in the way in which the state organizes its own loss of centrality. In other words, the withdrawal of the regulatory state - what has been called the deregulation of economic and social life - can only be achieved by state action, most of which must be accomplished through legislation.

The ways in which this state transformation is occurring are contributing to an increase in the functional heterogeneity of state action. Under often contradictory pressures, the different sectors of state action are assuming such different logics of development and rhythms, causing disconnections and incongruities, that sometimes it is no longer possible to identify a coherent pattern of state action, that is, a pattern common to all state sectors or fields of state action. This is related to the increasing duality between the intensely transnationalized sectors of social life and the nontransnationalized or only marginally transnationalized ones. The heterogeneity of state action is itself reflected in the total breakdown of the already shaky unity of state law, with the consequent emergence of different politics and styles of state legality, each of which operates with relative autonomy. In extreme cases such autonomy may lead to the formation of multiple microstates existing inside the same state. ${ }^{9}$ I call this new political formation the heterogeneous state. ${ }^{10}$ It is characterized by the uncontrolled coexistence of starkly different political cultures and regulatory logics in different sectors (e.g., in economic policies and family or religious policies) or levels (local, regional, and national) of state action.

${ }^{9}$ Sometimes such microstates are clustered around different ministries. For instance, the Ministry of Energy and the Ministry of Environment may operate under mutually incompatible political principles and regulatory logics.

${ }^{10}$ My first formulation of the concept of the heterogeneous state can be read in Santos (1995:274-81). 
Among the most significant factors accounting for the heterogeneous state are a disjunction between the political and administrative control over the territory and its people, the lack of integration among different political and legal cultures governing state action and the official legal system, and political and institutional upheavals caused by multiple ruptures occurring in rapid succession. All these factors are illustrated in "A Palimpsest of Political and Legal Cultures" with the case of Mozambique.

\section{Old and New Forms of Legal Pluralism}

Legal pluralism in contemporary African societies is today more complex than ever before, and in large part this is due to the processes of state transformation mentioned above. Until recently, the analysis of legal plurality was centered on the identification of local, intrastate legal orders, which coexisted in different forms alongside the official, national law. Today, alongside local and national legal orders, supranational legal orders are emerging, which interfere in multiple ways with the former. Subnational legal plurality acts in combination with supranational legal plurality. ${ }^{11}$

From a sociological perspective, the articulation among different scales of law becomes, ${ }^{12}$ therefore, increasingly complex. We can identify three scales: the local, the national, and the global. Each has its own legal norms and rationale, with the result that relations between them are very often tense and conflicting. These tensions and conflicts tend to increase as the articulations between the different legal orders and the different scales of law multiply and deepen. Whereas in colonial society it was easy to identify the legal orders and their spheres of action and thus regulate relationships between them-European colonial law on the one hand, and the customary law of the native peoples on the other ${ }^{13}$-in present-day African societies the plurality of legal orders is much more extensive and the interactions between them much denser. Paradoxically, if this denser relationship makes conflict and tension

11 On this subject, see Santos (2002:163-351), where the argument summarized in this section is developed at length. Legal pluralism is one of the core debates in the sociology and anthropology of law. See, among others, Nader (1969), Hooker (1975), Moore (1978, 1992), Galanter (1981), Macaulay (1983), Fitzpatrick (1983), Griffiths (1986), Merry (1988), Starr and Collier (1989), Chiba (1989), Benda-Beckmann (1988, 1991), Teubner (1992), Tamanaha (1993), Twining (1999), Melissaris (2004).

12 I use scales in the sense that they are used on maps rather than in the common metaphor of scales of justice.

13 This does not mean that the two legal orders existed separately, in two different worlds. On the contrary, the separation was a product of the intense and unequal interactions between them. Chanock was one of the first to show that customary law, far from being a survival, was created by the changes and conflicts brought about by colonialism (1998). The case of South Africa in this regard in both the pre- and post-apartheid periods is cogently analyzed by Klug $(2000,2002)$. 
between the different legal orders more likely, it also shows that the different legal orders are more open and susceptible to mutual influences. The boundaries between the different legal orders become more porous and each one loses its "pure," "autonomous" identity and can only be defined in relation to the legal constellation of which it is a part. Out of this porosity and interpenetration evolve what I call legal hybrids, that is, legal entities or phenomena that mix different and often contradictory legal orders or cultures, giving rise to new forms of legal meaning and action. In "Entangled Legal Pluralities: The Community Courts as Legal Hybrids," I illustrate the concept of legal hybrids with the case of community courts in Mozambique.

Situations involving legal hybridization as a new kind of legal pluralism challenge conventional dichotomies to the extent that legal practices frequently combine the opposite poles of the dichotomies and contain an infinite number of intermediary situations. Even so, on an analytical level, the dichotomies are a good starting point, as long as it is clear from the outset that they will not provide the point of arrival. The conventional dichotomies most relevant to analyze legal plurality in Mozambique are the following: official/unofficial, formal/informal, traditional/modern, monocultural/multicultural.

The official/unofficial variable results from the political-administrative definition of what is recognized as law or the administration of justice, and what is not. In the modern state, the unofficial is everything that is not recognized as state-originated. It may be prohibited or tolerated; most of the time, however, it is ignored. The formal/informal variable relates to the structural aspects of the legal orders in operation. A form of law is considered formal when it is dominated by written exchanges and norms and standardized procedures and, in turn, is considered informal when it is dominated by orality and common language argumentation. The traditional/modern variable relates to the origins and historical duration of law and justice. A form of law is said to be traditional when it is believed to have existed since time immemorial, when it is impossible to identify with any accuracy the moment or the agents of its creation. Conversely, a law is said to be modern when it is believed to have existed for a shorter period of time than the traditional and when its creation can be identified as to time and/or author. ${ }^{14}$ The monocultural/multicultural variable relates to the cultural universes in which the different laws and systems of justice

14 The complexity of this dichotomy has been widely debated in African postcolonial social science. See Copans (1990), Ela (1994), Gable (1995), Mamdani (1996), Werbner (1996), Chabal (1997), Fisiy and Goheen (1998), Mappa (1998), Mbembe (2000, 2001). 
occur. ${ }^{15}$ There is monocultural legal plurality whenever different laws and justices belong to the same culture and, conversely, there is multicultural legal plurality whenever the diversity of laws and justice correlates with important cultural differences (Santos 1995:506-19, 1997, 2002). Taking this set of variables or dimensions as starting points, I analyze in the following sections some of the most important features of legal plurality in Mozambique.

\section{A Palimpsest of Political and Legal Cultures}

A palimpsest is a parchment or other writing material written upon twice, the original writing having been erased or rubbed out to make place for the second or, more simply, a manuscript in which a later writing is written over an effaced earlier writing. In archaeology, the concept of palimpsest is used to refer to situations in which the same archaeological layers comprise objects and residues from very different periods and times and very often not accessible for exact dating. I use the metaphor of the palimpsest to characterize the intricate ways in which very different political and legal cultures and very different historical durations are inextricably intertwined in contemporary Mozambique. Their impact on state functions and actions is rendered by the concept of the heterogeneous state illustrated below.

During the 30 years of Mozambique's existence as an independent state, political-legal cultures as diverse as the colonial culture, the socialist culture, the democratic culture, and the traditional or community cultures have superimposed themselves on the country. The uneven embedding of these highly diverse political-legal cultures derives in great part from the political instability caused by multiple ruptures succeeding each other in fast pace. In fact, in the past 30 years, Mozambican society has experienced a series of radical political transformations, many of them traumatic, which have followed each other with dizzying speed. The following are the most significant:

1. the end of colonialism, which was violent up until its last period (starting with the national liberation struggle from the early 1960s until 1975)

2. a revolutionary rupture that aimed to build a nation from the Rovuma to the Maputo, ${ }^{16}$ a socialist society, and a "new Man" (1975-1984)

15 On the debate on multiculturalism and the law, see Khatibi (1983), Panikkar (1984, 1996), Lippman (1985), Sheth (1989), Le Roy (1992), Ndegwa (1997), Esteva and Prakash (1998), Tie (1999), Sánchez (2001).

16 These two rivers mark the north and south borders of Mozambique. 
3. the aggression of colonial Rhodesia and apartheid South Africa, in retaliation for the solidarity offered by Mozambique to the struggle for freedom in the region (from the late 1970s until the 1980s)

4. the civil war (from the end of the 1970s until 1992)

5. the collapse of the revolutionary economic model and its abrupt replacement, under external pressure, by the neoliberal capitalist model, which included both structural adjustment and the transition to democracy (1985-1994)

6. the construction of democracy (from 1994 to the present). ${ }^{17}$

All these transformations occurred as ruptures, as processes, which, instead of capitalizing on the positive features of previous transformations, aimed to sweep away all traces of them and make a new beginning, unable or unwilling to accommodate the immediate past. In reality, however, ruptures coexisted with continuities, blending explicit and self-proclaimed ruptures with unspoken continuities and so giving rise to very complex legal and institutional constellations and hybridizations.

Some of these constellations and hybridizations are the result of political decisions; others have proliferated in a more or less unacknowledged fashion, far removed from political proclamations. In these constellations, the most complex combinations occur between the cultures of greater historical duration (the traditional cultures and the colonial culture) and the cultures of a lesser historical duration (the socialist, revolutionary culture and the democratic, capitalist culture). The colonial political-legal culture, despite having been most thoroughly rejected-as exemplified by the notion of the escangalhamento do Estado (breaking up of the colonial state) during the revolutionary period-has prevailed up to the present day, not only in its most obvious forms, such as the colonial legislation still in force or the organization of the administration, but above all in terms of habits and mentalities, styles of behavior, representations of the other, etc. (Bragança \& Depelchin 1986; Monteiro 1999). It was within this culture that most of the senior civil servants who still ensure administrative routines today were trained.

Another legal-political culture that was rejected, although not quite so unconditionally, was the set of traditional or community cultures. Viewed as products of ignorance and as producing obscurantism and reactionary ideas, these cultures were seen as remnants and instruments of colonial culture. This attitude of rejection, which totally prevailed during the early post-independ-

17 For an evaluation of the last 30 years of political and economic history of Mozambique, see Chingono (1996), Minter (1998), Trindade (2003), Francisco (2003). 
ence years, came to coexist with another, more moderate attitude that favored a highly political and selective use of traditional cultures. For example, the creation of the popular courts, after the independence, sought selectively to co-opt traditional cultures, in order to make them serve the revolutionary culture (Sachs \& Honwana Welch 1990). ${ }^{18}$ In this early period, the constellation of political-legal cultures was dominated by the Eurocentric revolutionary socialist culture (henceforth, socialist culture). This culture, though based on the European revolutionary experience at the beginning of the twentieth century, also encompassed other nonEuropean experiences: Latin American (Cuba), Asian (China and North Korea), and African (African socialism, with a much less Marxist-Leninist outlook than the former and, in general, with a much less explicit set of doctrines, as exemplified in the case of Tanzania). Apparently the only legitimate one, the revolutionary culture coexisted, in fact, alongside the colonial culture and the traditional cultures.

From the mid-1980s onward, it was the turn of the revolutionary cultural component to retreat and give way to the primacy of Eurocentric democratic capitalist culture (henceforth, democratic culture). In contrast to the former, which was adopted as an autonomous option and mobilized predominantly internal energies, the democratic culture was adopted under strong external pressure, which nevertheless in no way excluded its genuine adoption by certain national political elites. Just as in the period when the revolutionary political-legal culture prevailed, the democratic culture brought with it profound political changes, including peace, subjection to global capitalism and the transition to democracy. Like the socialist culture, the democratic culture sought to be the only legitimate cultural reference. However, it had to exist alongside an altogether more complex cultural constellation, including not only the colonial and the traditional, the cultures of longer duration, but also the revolutionary culture of the previous period. The latter had transformed itself into an important institutional reality that, despite having been formally revoked, continued to operate on a sociological level. Thus, for example, the community courts, created during this second period (in 1992) to replace the popular courts of the previous period, ended up by ensuring the

18 The popular courts were considered to be "like a weapon permanently aimed at the class enemy, the reactionaries and the traitors, saboteurs of the economy and unscrupulous exploiters, criminals and outlaws throughout the country." The popular courts were, therefore, the instrument that enabled the population to "resolve the problems and difficulties which emerge in the life of the community, the local area, the village or the neighborhood." The popular courts were considered a guarantee of the consolidation and unity of the Mozambican people, "the great forge in which the people create the new law which is increasingly routing the old law of colonial-capitalist and feudal society" (Preamble to Law No. 12/78, 1978-author's translation). 
continuity of the popular courts, although under very precarious circumstances, as I show in the following section. Using the same facilities and staffed by the same judges who, in the previous period, had been popular judges, the community courts transformed themselves into a highly complex hybrid institution. In these courts, revolutionary, traditional, and community political-legal cultures combined. Eventually, the only absent culture was the one that supposedly had become the official legal and political culture - the democratic culture. In other sectors of public administration and legislation, different political-legal constellations were created. The revolutionary component, which was officially replaced by the democratic component, underwent, in fact, different metamorphoses and combined with the other cultural strains.

From this fusion of ruptures and continuities, a highly heterogeneous state action and a very complex matrix of legal pluralism have emerged that today dominate the legal and judicial system and, more generally, public administration. But a full account of these features of legal and political life in Mozambique requires that another, more recent, factor is brought under consideration: the heavy pressures of the globalization to which Mozambique has been subjected in the process of structural adjustment. I am referring more specifically to the impact of global factors on local and national conditions in circumstances in which the latter cannot consistently incorporate or adapt and much less subvert external pressures. Such pressures are both very intense and very selective, and by imposing their own specific regulatory logic, they result in profound changes in some institutions and legal frameworks. At the same time, other institutions and legal frameworks are left untouched and are therefore subject to their own logics.

This results in enormous fragmentation and segmentation, which affect the entire legal and administrative system. On the one hand, there are the transnationalized sectors, operating according to regulatory logics imposed by the multilateral financial agencies and the core countries. On the other hand, there are the nationalized or local sectors, operating according to hybrid and endogenous logics, which, being irrelevant for the transnational designs, are left to the national and local elites to exert their own political and personal differences on them. For example, the law of the financial and economic sector is today highly transnationalized and grounded in a single way of thinking promoted by global imperatives that leave little or no scope for internal political decisionmaking; at the other extreme, family law, for instance, is of little importance to the transnational powers and is therefore left in the hands of the national elites, who can lead intense political and cultural debates about it. The question of whether there is any underlying compatibility between the strikingly contrasting 
regulatory logics in these two legal domains is never addressed. The heterogeneity of regulatory logics lies precisely in these disjunctions, which, because they are unquestioned, go on being reproduced. ${ }^{19}$

The global pressures that have created legal and institutional plurality are of two basic types: pressures from the international financial agencies and so-called donor countries, which fall very specifically into the economic area, and pressures originating from the same agents, but principally from the foreign or transnational NGOs, which fall within what we may term social policy in the broadest sense. Both these pressures are very strong, so much that it is legitimate to ask whether we are not confronted with a situation of shared sovereignty between the Mozambican state and the foreign agents. In the field of economics, the segmentation created by structural adjustment between the transnationalized sector of the economy and the so-called informal sector is immense. It is a matter of two legal and institutional worlds whose actions are very often unfathomable. It is up to the state to keep them apart by managing this heterogeneity. On a strictly legal level, the heterogeneity of regulatory logics and the duality of legal and institutional worlds reproduce themselves in still another form. The two main subcultures of Eurocentric political-legal culture - continental civil law and Anglo-Saxon common law - are today engaged in what we could call a "global legal culture war." ${ }^{20}$ Breaking apart from the post-World War settlement, common law legal culture, especially in its U.S. law version, has come to assume, through globalization, an increasingly important role. This promotion of common lawwhich at times can be very intense - is carried out in countries with distinctive legal cultures and very different operational logics and methods from those that prevail in Anglo-Saxon legal culture. Therefore, discrepancies are created within national legal systems, which add up to the already high levels of state heterogeneity and legal pluralism. The official modern legal culture of Mozambique, which is inspired by continental European legal culture, has begun to experience the influence of Anglo-Saxon legal culture from two sides: through the policies of structural adjustment and, due to the proximity of and the close economic ties between the two countries,

19 This process of legal-institutional segmentation does not exclude the possibility of some legal or administrative sectors trying to bridge the two sets of existing regulatory logics. This is the case of the Land Law (Law 19/97, 1997). It remains an open question whether the building of this bridge, always a difficult task, will be solid enough to be sustained (Negrão 2003).

${ }^{20}$ I use the concept of global legal culture wars to highlight the extreme forms of competition among different legal systems particularly in peripheral countries and often linked to structural adjustment programs. Instances of such extreme forms of competition can be read in Santos (2002:208-15), Nader (2002), Dezalay and Garth (2002). 
through South Africa, whose legal culture is Roman-Dutch and Anglo-Saxon in origin. The latter influence is detected in both contract law and the legislative process.

In the "social area," the segmentations and shared sovereignties are even more complex. The complexity lies in the fact that different NGOs and, in many cases, the different core states behind them, have different concepts of what social intervention should be in such different domains as the fight against poverty, basic infrastructure, education, health care, protection of the family economy and the environment, etc. In other words, in the social sphere, global pressure is not only strong but also differentiated. Its strength still lies in the fact that the pressure, far from being conceived of as an imposition, is conceived of as international solidarity with a legitimate right to establish the terms of its implementation. As these terms vary from NGO to NGO and from donor country to donor country, and as NGOs and countries have concentrated their interventions in different regions or provinces of the country, the heterogeneity of social policies assumes a territorial nature. The consequent fragmentation and segmentation emerges as the result of complex negotiations, not only between foreign and international NGOs and donor countries on the one hand, and the national, state, and provincial and district governments on the other, but also as the result of the unequal relationships between the foreign and international NGOs and the national NGOs, which, in the vast majority of cases, are financially dependent on the former and therefore subject to their conditions.

The institutional and administrative fragmentation of the state thus results, in many cases, from anarchic superimpositions that generate exclusion and complaints from all those involved. Thus, the district government complains if an international NGO decides to operate directly and autonomously in the community. The provincial government (the administrative level above the district) complains about the decision of an NGO to support a municipality directly, without channeling this support through it. One or more national NGOs complain if an international NGO coordinates its aid with the provincial government and does not include the national NGOs working in the area. Provincial and district governments complain if international NGOs have decided to support particular areas or communities "without plausible reasons." Finally, international NGOs complain that the terms of their intervention are not defined by the national government, which means that they are seen as "parallel governments" when in fact they "only want to be partners." These reciprocal exclusions fuel the abovementioned disjunction between political and administrative control and transform administrative control into an appendage of political control. This transformation, which may occur in other 
contexts, is here particularly intense, and its specificity lies in the fact that it often involves the three scales (local, national, and global) of both law and politics.

In order to put an end to the most extreme forms of segmentation and fragmentation in state action, the government sought, through Decree No. 55/98 of October 13, 1998, to establish some measure of control over NGO actions. Article 6, No. 4 establishes that "it is the obligation of the central organ responsible for the NGO activity to indicate the province in which it will undertake its activities, bearing in mind the need to apply the principle of equity to the development of the country," and Article 2, No. 3 stipulates that "in the course of their activities, foreign NGOs are forbidden to undertake or promote any actions of a political nature." This decree has not yet been put to a test, and it is not difficult to imagine the problems its implementation will involve.

In a situation involving great segmentation of state, legal, judicial, and institutional practices, official deregulation is always less far-reaching than it is declared to be and re-regulation much less homogeneous than it intends to be. In these circumstances, the legal and institutional unity of the state is precarious, and the state appears often to be a set of microstates, at varying removes from each other, some local and others national or transnational, and all of them bearers of composite and distinct operational logics. This is the condition that characterizes both the heterogeneous state and legal pluralism under conditions of globalization. The characterization of legal pluralism is presented in detail in the following sections.

I conclude the analysis of the conditions accounting for the Mozambican state heterogeneity and legal plurality by focusing on the disjunction of political and administrative control, that is, on the state incapacity to guarantee either the separation or the equal territorial penetration of political and administrative control, thus tending to politicize administrative control and exercise it selectively. This is one of the most persistent legacies of the colonial state in Africa and has intensified in the last two decades due to neoliberal globalization, especially in the countries that gained independence most recently, as is the case of the Portuguese-speaking African countries. The overdimensioning of political control in relation to administrative control is evident in Mozambique. In administrative terms, the state is still confronting the problems of modern state-building - among them, the problem of state penetration, that is, of its effective political and bureaucratic presence in the whole territory. This situation encourages the politicization of the administration - for example, with the difficulties in transforming the results of elections into the sharing of power. It is feared that sharing power will involve a loss of administrative 


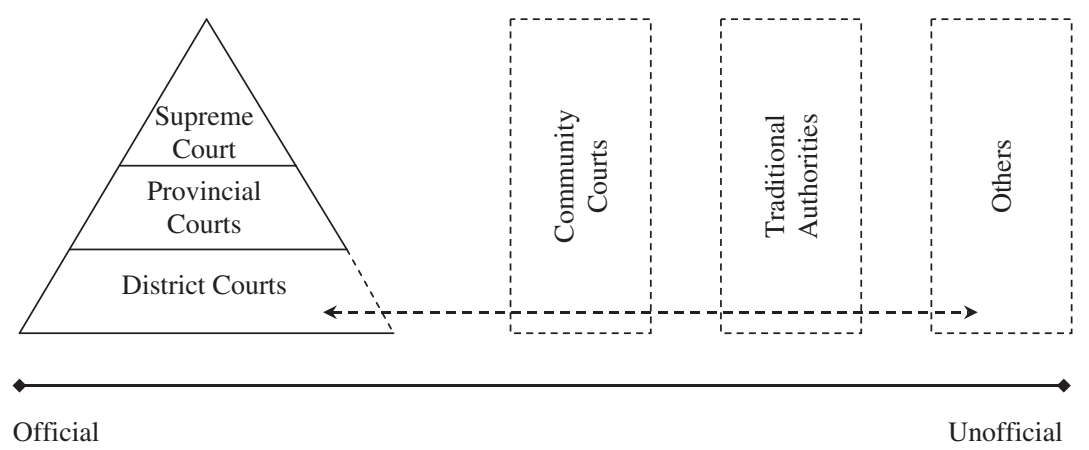

Figure 1. Legal plurality in Mozambique.

control, which is always imagined to be in the service of political control.

The disjunction of political and administrative control also results in the fact that, in its everyday practices, public administration has no means of guaranteeing its own efficiency. It therefore resorts to whatever institutions are locally available, whether they are structures from an earlier period, colonial or revolutionary ${ }^{21}$ which, in spite of having been legally eliminated or superseded, continue to survive as both political and administrative entities - or whether they are the traditional authorities (Geffray 1990; Dinerman 1999; Chichava 1999). These heterogeneous resourceswhich create a situation of bureaucratic bricolage - translate themselves in heterogeneous acts of administration caused by the coexistence of the formal and the informal, the official and the unofficial, the modern and the traditional, the revolutionary and the post-revolutionary. The following section illustrates some of these complex coexistences.

\section{Entangled Legal Pluralities: The Community Courts as Legal Hybrids}

In this and in the following section, I analyze some of the patterns of legal pluralism in Mozambique. As already indicated, Mozambican society is a vast and vastly differentiated social field of legal pluralism. Figure 1 gives a synthetic view of legal pluralism in Mozambique. In constructing it, I privileged the official/unofficial

${ }^{21}$ From the revolutionary period, all kinds of local political cadres, such as members of grupos dinamizadores, chefes de quarteirão, and secretários de bairro can still be drawn upon. Both urban settings and large rural villages are divided into neighborhoods (bairros). During the revolutionary period, each neighborhood had a local grupo dinamizador, ruled by a secretary (secretário de bairro). The large neighborhoods were subdivided into blocks controlled by chefes de quarteirão (each chefe de quarteirão controlled a given number of blocks). 
dichotomy. The pyramid on the left-hand side represents the official legal system, which includes 11 provincial courts and 90 district courts. The district courts are the lower courts and have more intense interactions with unofficial legal orders. In the unofficial legal orders, I distinguish three instances of conflict resolution, which, as the figure shows, are differently located within the continuum of official/unofficial. The first instance is the community courts, which I conceive here as a legal hybrid combining official and unofficial components; the second instance is the traditional authorities, and the third is a vast set of associations in which the religious associations, particularly the Muslim ones, stand out. In this section, I concentrate on the community courts.

There are no reliable data on the number of community courts and much less on the number of cases they handle. The number of judges varies from court to court, although a minimum of three judges is required to hear cases. In the courts analyzed, only 18 percent of the 144 judges are women. The judges, whether men or women, tend to be more than 40 years old. Even when they are replaced, recruitment does not, as a rule, alter the age group. However, particularly when the replacements are women, they do tend to be younger. In terms of occupation, the majority of the community courts' judges may be considered rural workers (most of them women), followed by those who are retired, craftspeople, or factory workers. By and large they handle cases relating to family matters, followed by theft, injuries, and physical aggression. There are also cases relating to debt, land issues, housing issues, and witchcraft accusations.

There are significant differences among the courts in the ways they operate, whether in terms of procedural or substantive norms. A few courts selectively adopt the styles, formulas, and language of official justice, with all the proceedings being registered in writing. In most cases, however, informality and orality prevail. Even in more formalized proceedings, the use of judicial formulas is combined with the use of common language, directly linked to the oral nature of the surrounding culture. In any case, the formality does not influence the decision. It seems, above all, to have the aim of creating an institutional distance in relation to the parties and of legitimizing the power of the court. All the hearings take place in a context dominated by rhetoric, that is, by common language argumentation. National languages predominate (there are more than 20 languages in Mozambique), and the court usually speaks in the same language as the parties, with no need for interpreters. ${ }^{22}$

${ }^{22}$ For the official judges this is problematic, since the official legal language-Portuguese - is neither the mother tongue nor the language normally used by the majority of Mozambicans. 
In Mozambique, the community courts are the legal hybrid institution par excellence, particularly in what concerns the official/ unofficial dichotomy. They are recognized by law-they were created by Law No. 4/92, of May 6, 1992-but their operation is not regulated by law, nor are they part of the official legal system (for instance, there is no appeal to the official courts from the decisions of the community courts). ${ }^{23}$ The decision to remove them from the judicial system was justified with the new conception of the rule of law introduced along with structural adjustment. The decision was in tune with the political atmosphere of the time, interested in eradicating from the state any remnants of the popular power institutions of the previous, revolutionary period. The community courts were thus left in an institutional limbo. Because they decide cases "with impartiality, good sense and equity" (Article 2, No. 2, of Law No. 4/92) but not according to law, they are not considered part of the judicial system. They should, however, become organs of justice "for the purposes of reconciliation or the settling of minor disputes" (Article 63 of Law No. 10/92, 1992) as a type of community justice for which there are words of praise in the law: "bearing in mind the ethnic and cultural diversity of Mozambican society" (Preamble to Law No. 4/92). The Preamble also states that the community courts will "enable citizens to resolve minor differences within the community, contribute towards harmonizing the diverse practices of justice as well as enriching rules, uses and customs and lead towards a creative synthesis of Mozambican law." Being neither entirely official nor entirely unofficial, the community courts are a legal hybrid, both inside and outside of official law and justice.

Left in this limbo, the community courts have taken on the legacy of the popular courts, which have, in the meantime, been formally abolished. The law that created the community courts determined that the judges of the local and neighborhood courts (that is, the popular courts of the previous, revolutionary period) would continue to exercise their functions until the first elections for judges of the community courts were held. As there were no elections, the judges at the time kept their positions. Death, illness, war, and migrations caused the number of judges to be reduced over the years. Moreover, some judges left their posts due to the loss of social prestige attached to the position and the feeling of being "abandoned" by the government. In the absence of any regulatory law to define rules of recruitment, these replacements

23 The law that created the community courts established that before the courts could operate, a new law would be promulgated defining their jurisdiction and their institutionalization. Such a law has not been promulgated up until now. The Mozambican Parliament has decided to pass the law of the community courts in 2005 . 
were made from within the same sociopolitical environment as that of the previous judges. The new judges were selected by neighborhood structures or by the direct intervention of the ruling party, Frelimo. ${ }^{24}$ For this reason, almost all the judges interviewed for this article said they belong to the Frelimo Party, and many of them also participate in party organizations. This hybridization between political and judicial functions is also at the root of the problems confronting the community courts. The fact that the community courts continued to operate very much like the popular courts (formally eliminated at the end of the revolutionary period) in terms of both personnel and premises has favored the adherence to the Frelimo Party. This fact has led to the political polarization of community justice, in that community courts are considered instruments of Frelimo and the traditional authorities instruments of Renamo, the main opposition party. ${ }^{25}$ This polarization reached some extremes when, for example, a group of judges, who are supporters of Renamo, decided to create a parallel community court in Mocímboa da Praia (in the northern Province of Cabo Delgado).

The judges interviewed resent the lack of support from the state: lack of basic stationery, lack of financial compensation for their work, lack of training or guidance on procedural rules, and a lack of solidarity on the part of the district courts to whom social cases are referred by the judges. In 10 of the 34 courts analyzed, there are not even enough judges to allow the court to function with its legal minimum quorum (two members in addition to the president). Other courts, although composed of three or more judges, are very often obliged to function without a quorum whenever one or several of the judges are, for some reason, unable to attend. The community courts operate at the same locations that the popular courts used to operate, which are usually quite precarious. Of the 34 courts observed, eight were held in the open air, and 18 functioned in locations offered by the local political organization of the Frelimo Party, by the local administration, or by the school director or the Municipal Council. Moreover, two courts functioned in the house of the judge that presided over the court, one on the porch and the other in the garden; only six courts had

24 Frelimo was the movement that conducted the struggle for national liberation. After Mozambique's independence, Frelimo underwent a process of political transformation and was established as a party in the late 1970s. After the introduction of a multiparty system, in the early 1990s, Frelimo won the three first presidential and legislative elections, thus becoming the party in power.

25 Renamo emerged as a movement of resistance against Frelimo, carrying out a civil war for more than a decade. After the 1992 peace agreement between Renamo and the Mozambique government, Renamo transformed itself from a movement of resistance into a political party, becoming the major opposition party in the country. 
their own premises. Functioning in the open air gives the court a seasonal character. Whenever it rains, the activities of the court have to be interrupted.

Functioning in premises offered, in the majority of cases, by the local political organization forces the community courts to share the space, which affects the working hours of the court. In several cases, judges warned the parties or the witnesses during the trial sessions to keep to the timetable of the court because after that the room would be occupied "by others." Moreover, sharing premises interferes in many other ways with the activity of the court as, for instance, when trials are disturbed by members of other entities sharing the same location (for example, the grupo dinamizador, the Frelimo Party, etc.) entering frequently to consult documents filed there, fetch papers, etc. The lack of their own premises prevents the community courts, in general, from having any space for their exclusive use to keep and file away their documentation. In 15 of the courts observed, case files and other documentation are stored in the house of the presiding judge or the secretary.

The hybrid character of the community courts does not limit itself to the legal/political or official/unofficial variables. It can be traced in each of the dichotomies that define the terms of legal plurality and also in the constellation of legal cultures (revolutionary, traditional, and liberal democratic legal cultures) present in the ways the courts operate. The extreme variety gives rise to a landscape of chaotic spontaneity. Lacking, in general, institutional support, and competing with other mechanisms of dispute resolution - ranging from the police and the local political cadres informally performing judicial functions to the traditional authorities and church organizations - the community courts rely on themselves and their skills for improvising, innovating, and, in the end, reproducing themselves. Some remain very active, while others are moribund; some beat the competition offered by other institutions involved in dispute resolution, while others are rarely resorted to by community members.

The palimpsest nature of the political and legal cultures in contemporary Mozambique mentioned in the previous section is most vividly illustrated in the legal reasoning and procedural style of dispute resolution in the community courts. Some courts function predominantly within an official, formal atmosphere whilst others assume an unofficial, informal character. Some operate within a revolutionary logic, placing political loyalty above everything else, while others have fully accepted the new times and the pragmatism demanded by communities mainly interested in peaceful survival. Some seek to affirm their autonomy in relation to the local administrative authorities (which are themselves a politicaladministrative hybrid), the religious authorities, and the traditional 
authorities, while others are totally subordinate to the administrative authorities and assume a multicultural character, resorting to the traditional authorities in many cases, such as when dealing with witchcraft or family problems. ${ }^{26}$ However, no matter which type of legal reasoning or procedural style predominates, it operates in complex articulations with other types or styles. In this way, varying according to the courts, the cases, the nature of the dispute, or the status of the parties, different "layers" of formalism and informalism, of revolutionary rhetoric and pragmatic rhetoric, of practices of autonomy and practices of networking are differently combined but always inextricably intertwined.

Finally, though most courts have no working relationship with the district courts, some do. In the revolutionary period, the district courts, then called popular district courts, were the bridges between the law courts and the popular courts, establishing both complementary and competitive relationships with the latter. This type of articulation continues today, however sporadically and informally. For example, the district courts make use of the community courts and the traditional authorities to ensure that court summonses are complied with. In the district of Mueda (Cabo Delgado Province), the district court and the community courts in the district capital maintain a stable relationship, which has progressed from the discussion of jurisdiction of the community courts to the joint definition of the sanctions to be applied in various cases and on the rapid handling of cases that are referred to the district court by the community courts. In addition, a form of "division of legal labor" has developed: family matters, for instance, are referred by the district courts to the institutions of community justice. According to one district court judge interviewed, these types of conflicts "are not for a judge to hear, but should be resolved within the family or in the neighborhood." In this context, the police often take on the function of distributing litigation among the different institutions, according to the agreed-upon informal rules of jurisdiction.

Through this chaotic web of actions and omissions, of communication and noncommunication among different institutions, practices, and cultures, the community courts do contribute to "a creative synthesis of Mozambican law," except that they do so under very precarious circumstances and indeed outside the law. The legal limbo has played against the community courts. A void has been created that has been filled by other mechanisms of social regulation, with the traditional authorities emerging as the most important of all.

26 The community courts also resort to the Mozambican Association of Traditional Doctors (AMETRAMO) in cases of witchcraft (see also Meneses et al. 2003). 


\section{Multicultural and Multiethnic Justices: The Case of the Traditional Authorities}

Throughout this article, I have emphasized the multiple and culturally diverse instances of dispute resolution and community justice in Mozambican society, in both rural and urban environments. In addition to community courts, traditional authorities and social, cultural, religious, and regional associations function as instances of conflict resolution. The most important of the latter associations are the churches and, within them, Islamic organizations, which have been growing in influence in recent years. Because it does not recognize any strong distinction between the religious and the nonreligious, the Islamic faith tends to regulate social life as a whole. In the center and northern regions of the country, where the Islamic presence is historically more powerful, religious law has become an important component of legal plurality, particularly in family matters. This is a field of intense hybridization between religious law and traditional law. All this vibrant legal life occurs outside the official legal field, mobilizing legal and political cultures that have very little to do with the legal and political cultures underlying the official legal system. Legal polycentrism merges here with multiculturalism and, thus, with multicultural legal plurality. But of all the instances of multicultural legal plurality, the traditional authorities are by far the most important, not only because of their role in dispute resolution but also because of the political contention around them. ${ }^{27}$

In order to understand the political context in which the traditional authorities operate in Mozambique, it is imperative to locate it in the broader, African context. The traditional authorities are debated throughout the African continent. There are many themes to the discussion, and the following may be highlighted: the traditional authorities as local power and administration, the regulation of access to land, women and traditional power, witchcraft, traditional medicine, and the compatibility between traditional law and official law and, in particular, the Constitution. From the perspective of neoliberal globalization, the traditional authorities are the paradigmatic example of what cannot be globalized in Africa. From this perspective, what cannot be globalized is of no interest to neoliberal globalization and, as such, can be easily stigmatized as an African particularity, an obstacle to the opening up of African societies to the virtues of the market economy and liberal democracy. Yet what becomes the object of stigmatization may be reappropri-

27 The role of traditional authorities in conflict resolution in Mozambique has been emphasized by several Mozambican researchers. See, among others, Cuahela (1996), Honwana (2002), Meneses (2004). 
ated by the subaltern social groups as something positive and specific, as a source of resistance against an excluding global (Western) modernity. It is exactly this reappropriation and resignification that has begun to take place in the area of traditional power. Today, the recovery of the traditional in Africa, far from being a non-modern alternative to Western modernity, is the expression of a claim to an alternative modernity. Because it is occurring throughout Africa and indeed throughout the global South, it is a form of globalization that presents itself as resistance to globalization.

One of the most visible modernizations of traditional authority lies in the way that modern state elites seek out non-modern, traditional legitimacy to reinforce their power. However, this process also occurs in reverse, whenever the bearers of traditional power seek to promote their children or families to a political career in the service of the state, to consolidate and reinforce the traditional power they possess and see threatened by state competition. This double-edged power struggle can result in conflicts that are difficult to resolve. The ethical code of modern power is based on a distinction between public and private and on the primacy of common interests over sectoral interests. In contrast, the ethical code of ethnic power is based on community interests and relates to a community made up of both living people and their ancestors, in which modern distinctions make little sense. Thus, from the perspective of the modern political ethical code, a particular political or administrative action may be considered as corruption, favoritism, nepotism, patronage, or privatization of the state; but when evaluated from the point of view of the traditional ethical code it may be considered as the fulfillment of family obligations and the exercise of community or ethnic loyalties. The popular saying "The goat eats wherever it is tethered" illustrates this ambiguity or duality.

The question of how to articulate this dual legitimacy feeds one of the most intractable debates in Africa today. ${ }^{28}$ According to one argument, the two powers and the two legitimacies must be kept separate, even if they are conferred upon the same person. In other words, state political actions or actions within the public arena of modern civil society must be based exclusively on modern ethical codes, whilst community actions and rituals must be based exclusively on traditional ethical codes. According to another argument, this separation, even if correct-which is debatable-is impossible to sustain, given that individuals cannot keep their multiple identities watertight and "uncontaminated." It is better,

28 In a different way, the question of dual legitimacy also exists in Latin America after the emergence of the multicultural constitutionalism of the late 1980s and early 1990s (the constitutional recognition of the political and legal identity of the indigenous peoples). 
therefore, to assume that contamination and hybridization between codes is a "natural" condition. ${ }^{29}$

The rules for this dual-edged power game vary from country to country and according to the historical, cultural, and political context. In countries that are officially democratic, these conflicts must be settled by electoral means and according to the rules imposed by the political system in force. Nevertheless, it does happen that, due to the factors already mentioned, electoral legitimacy cannot sustain itself, leading to frequent reliance on community, ethnic, or traditional resources. Ethnic power can thus be manipulated so that in certain situations it functions as a threat and in others as an opportunity. According to circumstances, the political elites wrangle amongst themselves, either for the modern political path, using ethnic power as a resource, or for the traditional political path, using electoral power as a resource. Herein lies a fertile field for the proliferation of political hybrids that are structurally similar to the legal hybrids identified in the previous section.

In the history of Africa, this is not the first time that traditional authorities have been politicized or politically manipulated. This was also the case during the colonial period, particularly from the end of the nineteenth century onward. It is known that traditional authorities were used by colonial powers as a means of ensuring the abovementioned disjunction between direct political control and indirect administrative control. And indeed, the current situation in Mozambique shows a remarkable continuity with the colonial period. To limit myself to the twentieth century, the establishment of a dual, racialized civil society was formally recognized in Estatuto do Indigenato (The Statute of Indigenous Populations) adopted in 1929. The Estatuto established a distinction between the "colonial citizens," subject to the Portuguese laws and entitled to all citizenship rights effective in the "metropolis," and the indigenas (natives), subjected to colonial legislation and, in their daily lives, to their customary, native laws. Between the two groups there was a third small group, the assimilados, comprising blacks, mulatos, Asians, and mixed-race people, who had some formal education, were not subjected to forced labor, were entitled to some citizenship rights (a kind of second-class citizenship), and held a special identification card that differed from the one imposed on the immense mass of the African population (the indígenas), a card that the colonial authorities conceived of as a means of controlling the movements of forced labor (CEA 1998). The indígenas were subject to the traditional authorities, who were gradually integrat-

29 This, however, raises serious questions, such as, for example, the issue of determining criminal liability in cases considered by official law to be active or passive corruption or abuse of power. 
ed into the colonial administration and charged with solving disputes, managing the access to land, and guaranteeing the flows of forced labor and the payment of taxes (mainly the hut tax). As several authors have pointed out (Mamdani 1996; Gentili 1999; O'Laughlin 2000), the Indigenato regime was the political system that subordinated the immense majority of Mozambicans to local authorities entrusted with governing, in collaboration with the lowest echelon of the colonial administration, the "native" communities described as tribes and assumed to have a common ancestry, language, and culture. The colonial use of traditional law and structures of power was thus an integral part of the process of colonial domination (Young 1994; Penvenne 1995; O'Laughlin 2000) obsessed with the reproduction of the super-exploitation of African labor.

In the 1940s, the integration of traditional authorities into the colonial administration was deepened. The colony was divided into concelhos (municipalities), in urban areas, governed by colonial and metropolitan legislation, and circunscrições (localities), in rural areas. The circunscrições were led by a colonial administrator and divided into regedorias (subdivisions of circunscrições), headed by régulos (chieftains), the embodiment of traditional authorities. Provincial Decree No. 5.639, of July 29, 1944, attributed to régulos and their assistants, the cabos de terra, the status of auxiliares da administração (administrative assistants). Gradually, these "traditional" titles lost some of their content, and the régulos and cabos de terra came to be viewed as an effective part of the colonial state, ${ }^{30}$ remunerated for their participation in the collection of hut taxes, recruitment of the labor force, and agricultural production in the area under their control. ${ }^{31}$ Within the areas of their jurisdiction, the régulos and cabos de terra also controlled the distribution of land and settled conflicts according to customary norms (Geffray 1990; Alexander 1994; Dinerman 1999). To exercise their power, the régulos and cabos de terra had their own police force. This system of indirect rule illustrates what the disjunction between political and administrative control refers to above. It continued after the Indigenato system was abolished in the early 1960s. From then on, all Africans were considered Portuguese citizens, and

30 Despite this linkage with the colonial administration, several authors refer to the dual role of some régulos who used their privileged positions to promote programs that improved the life conditions of their populations (Isaacman 1990; Alexander 1994). In other situations, they made a decision to confront the colonial system directly or to flee to neighboring countries (Vail \& White 1980; CEA 1998).

31 An example of this is Article 2 of Municipal Decree No. 13.128, from April 1950, which granted the traditional authorities certain concessions for their interference into labor contracts; the Boletim Oficial No. 2469/B/2 of the Central Division of Indigenous Affairs, of June 25, 1952, regulates, among other issues, the uniforms for traditional authorities. 
racial discrimination became a sociological rather than a legal feature of colonial society. The rule of traditional authorities was indeed integrated more than before in the colonial administration.

After the independence, Frelimo took a hostile position visà-vis the traditional authorities conceived of in a broad sense, including régulos, healers (curandeiros), religious leaders, etc. Seen as obscurantist remnants of colonialism and as fomenting regional and ethnic differences, party members saw no place for them in the construction of a supra-ethnic state, a national culture, and a model of development aimed at liberating Mozambique, in a few generations, from the shackles of underdevelopment. The first Constitution of Mozambique, approved in 1975, declared in its Article 4 the "elimination of colonial and traditional structures of oppression and exploitation and the accompanying mentality." Régulos were then replaced by the new political structures at the local level, the base-level party cells, the grupos dinamizadores (dynamizing groups). In tandem with the popular courts, they took over the functions previously entrusted to the traditional authorities.

The legal abolition of traditional authorities proved to be a complex political and social problem for the government in the following years. To begin with, there were no resources to deploy the new political-administrative structures throughout the whole country, and where they were deployed they were not automatically accepted by the populations. As a result, the traditional authorities continued to rule under different forms and conditions. Both the popular courts and the grupos dinamizadores resorted to them in search of guidance and legitimacy. In the process, some régulos became judges of the popular courts, deciding the cases on the basis of traditional law and justifying their decisions in terms of revolutionary legality. Another source of problems for the government came with the rise of Renamo. Renamo, which was initially credibly seen as a product of the South African secret services, gradually took roots in some regions of the country feeding on the frustrations of the populations with some misguided state policies and with the immense gaps between promises and delivery. Ostracized by Frelimo, the traditional authorities saw in Renamo an alternative to recoup their power and prestige. A bloody civil war throughout the 1980s further undermined the administrative and welfare capacities of the state and deepened the political polarization around the traditional authorities. Such polarization, combined with the state's docile compliance with neoliberal impositions from the mid-1980s onward, fuelled the process by which the traditional became a way of claiming an alternative modernity.

Since 1992, the government has been trying to address the issue of the politicization of base-level governance: community courts, seen as heirs of the popular courts and close to Frelimo, on 
one side, and traditional authorities, seen as a legitimate source of power and close to Renamo, on the other. ${ }^{32}$ The government responses have been twofold. On the one hand, until recently, as I showed in the previous section, the government has seen no urgency to reformg the community courts. The reform is now under way, and it is an open question whether the new law of the community courts will be truly bipartisan and therefore likely to survive any changes in government in the future. On the other hand, the government has been trying to neutralize the hostility of traditional authorities, co-opting them by granting them some kind of subordinate recognition and participation in local administration in the rural areas.

The strategy of co-optation relies on the disjunction between administrative and political control. Decree No. 15/2000, of June 20, 2000, the Law of Community Authorities, illustrates the intention of the state to benefit from the administrative abilities of the traditional authorities and simultaneously to neutralize any centrifugal energy they might harness in terms of the political control of populations. As the preamble to the Decree states, the community authorities are recognized within the realms - and, therefore the limits - "of the process of administrative decentralization, bettering the social organization of local communities and improving the terms of their participation in public administration." Article 2, in turn, establishes that

in carrying out their administrative functions, local organs of the state will interact with the community authorities, by listening to opinions on the best way to mobilize and organize participation from the local authorities, in the design and implementation of economic, social and cultural plans and programs, designed to benefit local development.

No political effect, particularly in terms of participatory democracy, is recognized in these processes of listening and interaction. Finally, Article 3 defines the limits of recognition that refer to the political Constitution and statutory law in general. The general limit is formulated in Article 3, No. 1, and No. 2 underlines the pragmatic and instrumental nature of the recognition of community authorities,

32 This formulation represents the general tendency. Of course, many traditional authorities publicly side with Frelimo. In this regard, the plasticity of traditional authorities is eloquently illustrated by the institutional innovation of the régulo of Mafambisse (Sofala province) during the civil war. During the course of the war, the régulo's territory was torn apart by Frelimo and Renamo conflict. In order to preserve the traditional leadership in the area, the territory was divided into two zones. The zone under the control of the Renamo continued to be ruled by the titular régulo, Manuel Dique Mafambisse, who came from a prestigious family. In the zone under government control, the traditional authority was represented by the then local political leader, José Dique Mafambisse, younger brother of the titular régulo. 
since the criteria for participation are based exclusively on the "needs for administrative service."

This recognition pattern and the politics underlying it bear a clear continuity with the colonial past, which is also visible in some of the rights and privileges conferred upon the traditional authorities: the use of symbols of the Republic, participation in official ceremonies, the use of their own uniform or distinctive clothing, and the receiving of a subsidy as a result of helping the state in collecting taxes (Article 5). The main difference in relation to the colonial period lies in the fact that the state sought to neutralize the traditional authorities not only through the strict separation between political and administrative functions but also through the integration of traditional authorities into a broader set of local government involving base-level administrative structures and even the political-administrative hybrids I mentioned above. The colonial state, on the contrary, emphasized the specificity of traditional authorities in order to justify the racialization of state and society. Specificity meant the natural inferiority of traditional authorities vis-à-vis modern colonial rule, of African culture vis-à-vis Western culture, and of indigenous peoples vis-à-vis colonial citizens.

In Mozambique and in Africa, in general, there are today two contrasting views concerning the specificity of traditional authorities: according to one of them, traditional authorities are one among several types of local authority and should be granted no privilege among various other types of authority existing in the same community; according to the other, the traditional authorities are not on equal footing with other local authorities, since they alone control the power of the spirits and the power of the ancestors, so decisive in the government of the community because of their access to rituals and the magical aspects of community life. ${ }^{33}$ The already mentioned Decree No. 15/2000 of June 20, 2000, on local community authorities, adopts the first argument. According to Article 1, "under the terms of the present Decree, the community authorities are understood to be the traditional chiefs, the neighborhood or village secretaries and the other legitimate leaders recognized as such by the respective communities."

Below or parallel to this official politics of recognition and control flows an intense and chaotic web of interlacings among different legitimacies, local powers, legal cultures, and legal practices. While in the revolutionary period the popular courts and grupos dinamizadores sought the guidance and support of the

33 On the first view, see Ghai (1991), Nzouankeu (1997), Mamdani (1999). On the second view, see Ayittey (1991), van Rouveroy van Nieuwaal and van Dijk (1999), Williams (2004). 
traditional authorities and settled many disputes by resorting to them, even though they had been officially abolished, today the official patterns of recognition of traditional authorities and the "return to tradition" say very little about the traditional rule in action. Actually, this varies according to the region; the prestige of the régulo or healer; the relative penetration of the state institutions; the kinship relationships among traditional authorities, state administrators, and base-level party organizations; and, finally, the relative strength and implantation of alternative community structures of conflict resolution in community courts, Muslim organizations, churches, NGOs, etc. A meshwork of regular or sporadic interactions and negotiations is in place whose unfolding depends as much on the practice of the different institutions involved as it does on the initiative of citizens and social groups interested in turning to their advantage the existence of such competitive or complementary plurality.

Within this meshwork and plurality, the "return to the traditional" seems to have more and more appeal, particularly in rural areas where the vast majority of the population lives. A growing activism on the part of the traditional authorities has been identified, and the involvement of political or administrative cadres in traditional ceremonies has been accepted. Respect and mutual tolerance have grown. Although it appeared in the early 1990s that most of the traditional authorities were intervening only in religious or spiritual ceremonies as a way to promote peace (Alexander 1994; Honwana 2002), the situation today points to a broader intervention that is particularly sought for whenever the other local authorities are unable to resolve problems and conflicts. ${ }^{34}$ In these forms of cooperation, the abovementioned duality of traditional and modern legitimacies dominating law and politics in Africa surfaces very clearly, especially at the local level. ${ }^{35}$

This is the complex historical, social, and political context in which traditional authorities operate today as instances of conflict resolution. Among all the dimensions of legal pluralism in Africa, the traditional authorities and their law (traditional law, kinship

34 Depending on the situation, some traditional leaders directly offered their services to the state without conditions, in order to recoup the role they had before it was disrupted by politics or by the war; others, concerned with the question of status and social recognition, are still waiting for formal state recognition of their authority (materially translated in goods and services such as housing and uniforms).

35 This climate of cooperation does not prevent the traditional authorities from remembering past grievances and from voicing them when deemed appropriate. Régulos and their assistants were intimidated and humiliated by their former subjects who came to occupy party secretary positions within the Frelimo, or by higher-level state and party authorities (Geffray 1990). Due to political motivations and the climate of animosity, some traditional chiefs were deported to the northern provinces and forced to work in the now infamous "Operation Production" launched in the early 1980s. 
systems, African customs, and customary law are some of the terms currently used) have for a long time been the most significant. What distinguishes the legal pluralism they promote is the saliency of the modern/traditional variable and the monocultural/multicultural variable. What is common to the different conceptions of the traditional authorities is the idea that these legal practices are distinct from the Eurocentric symbolic and cultural universe that underlies official law and justice. Traditional law and justice, therefore, raise two very complex questions: the question of what is traditional and the question of what counts as multicultural. Both of these questions are very widely debated issues today, and this debate is not only academic but also political. What is at stake is, once again, the relationship between the political control and the administrative control of populations and their territories, and particularly the question of the legitimacy of the power needed to secure either form of control.

As dispute resolution mechanisms, the traditional authorities are particularly important in issues of access to land, family, debt, bodily harm, damage to property, health/sickness, witchcraft, and petty theft - indeed a very broad range of issues. In all these matters, the traditional authorities are a key node in a network of institutions that may include the district or even the provincial courts, the police, and local political and administrative agencies. Sometimes they are the first venue sought for by the parties, while other times they function as appeal institutions, and in still other cases they provide advice or evidence in cases being dealt with by other institutions.

One of the great strengths of the justice provided by the traditional authorities is its immediate, public, collective, face-to-face, and relatively transparent character. The hearings normally take place in the régulo's house, porch, or garden. The frequency of these hearings varies. Certain days might be selected for the hearing, or hearings might occur when people solicit the help of the régulo. In the cases we observed, most of the régulos tend to hold hearings on the weekend, particularly on Sunday. The dispute resolution is dominated by rhetoric and orality, as in community courts. And as in the case of community courts, the language used is by large the local language of the parties, with no need for interpreters. The participation of the régulo and of his associates is central. In the regions surveyed, no case was found of a woman being a régulo. However, a significant number of women are traditional healers. Among the counselors of the régulo there are normally one or two women. The régulo (and occasionally his counselors or assistants) sit at a table, on a more elevated plane. The parties are seated on a lower level, either in the front or on the sides. The audience sits on benches or mats. The régulo leads the 
hearing. After the session is opened, the person issuing the complaint and the accused normally make their case. Because the sessions are open to the public, the members of the audience are normally invited to participate by presenting their explanations of the problem. This is a very important part of the process of conflict resolution. Indeed, adults are allowed to question witnesses and give their opinion on the case.

The régulo's counselors (madoda) also offer their appraisal of the conflict. When the case involves witchcraft accusations, the opinions of the madodas are important concerning the decision to appeal to healers or to AMETRAMO (the Mozambican Association of Traditional Doctors). ${ }^{36}$ At times the healers intervene and give a deposition.

Once he has heard and considered the problem, the régulo deliberates. In most cases, the régulo tries to obtain a consensus from both parties in order to maintain social equilibrium. Whenever an offense has been committed and must be punished, the main types of punishment are fines, community service, or corporal punishments such as head-shaving and chambocadas (flogging). Although prohibited by law, corporal punishment still appears to be practiced. Several régulos showed nostalgia for these sanctions: "In the old days the authority took action. The person was tied up and beaten. Now the authority can't beat people any more" (interview with the régulo Phata, Inhambane province). In the case of the regulado of Luís (Sofala province), there was a cell in the headquarters.

In the field of conflict resolution, the relationships of the traditional authorities with other local authorities are quite complex, not always free from conflicts or tensions. Forms of cooperation are also present: many régulos send matters of divorce to the community courts; serious crimes - such as homicide - are sent to the police.

This analysis shows that the traditional authorities are carving out their judicial and political space in the new legal and political framework, both when effectively implemented and when left to the indeterminate play of competing local legal and political forces. They are doing so using a vast array of means available to them, some ancestral and others very recent, but all of them used in

36 As Meneses shows in her research on traditional medicine in contemporary Mozambique, the power of the nyanga (traditional healer) resides in his or her ability to identify existing social tensions, contradictions, and areas of distrust, as well as the possible antisocial hostilities that could manifest themselves as sickness, bad luck, or even death in the community (Meneses 2004). The process of identifying the witch doctor, locating that agent of evil, and making him or her confess their actions, is also the process by which witch doctors are cleansed of the burden of evil, thereby opening the door for the restoration of equilibrium and good health in the community. Even in the revolutionary period, the popular courts would often turn to the traditional healers in order to solve cases involving witchcraft accusations. 
modern competitive or complementary interactions with all the other nodes of a mixed, inherently hybrid regulatory network. Out of this network, new forms of democratic rule may be emerging, which call for careful analysis. Under the new laws that regulate the process of recognition and legitimization of "local leadership," régulos and other community leaders may be required to secure the basis of their legitimacy through a broad process of popular consultation. By opening some space for negotiation in the choice of régulos, cabos de terra, madodas, healers, etc, this process, although incipient, includes elements of participatory democracy.

\section{Conclusion}

In this article, I have highlighted some hidden dimensions of the current global call for legal and judicial reform, namely the ways in which it seems to be operating as if the developing countries were a legal and judicial tabula rasa. The rich social experience of diverse legal and judicial practices thereby ignored is the main focus of this article. More specifically, I focused on the Mozambican state and society and on the rich landscape of legal pluralism that characterize them. I proposed the concept of the heterogeneous state to highlight the breakdown of the modern equation between the unity of the state, on the one hand, and the unity of its legal and administrative operation, on the other. I explained the most salient features of the heterogeneous state and of legal pluralism in Mozambique in terms of three major factors: the impositions of neoliberal globalization and their impact on the political and social processes; an African cultural heritage, the object of intense debates and with deep implications for law and politics; and the nature and role of the state, bearing in mind that the latter emerged from colonialism in the last quarter of the twentieth century. I tried to highlight the complexity of legal and political processes in a country that has been independent for less than three decades; that has undergone, in such a short period, a turbulent succession of contrasting political regimes and cultures; and that has suffered a bloody civil war for more than 10 years and since 1994 has been trying to consolidate a transition to a liberal democratic regime.

I expanded on the concepts of legal hybridization with the purpose of showing the porosity of the boundaries of the different existing legal orders and cultures and the deep cross-fertilizations or cross-contaminations among them. Among the many instances in which these conceptions could fruitfully unfold, I focused on community courts and traditional authorities. I reconstructed the multicultural legal plurality resulting from the interaction between 
modern law and traditional authorities as a multicultural legal plurality involving alternative modernities.

The future of the conditions accounting for the heterogeneity of the state and legal pluralism is tied to the future of the Mozambican state and society, as an encompassing process, and will tend to decrease in importance in any scenario in which the following developments will occur: democratic stability and sustained social and economic development able to break the cycle of successive politicalinstitutional ruptures; deepening democracy so that political control and administrative control can develop with reciprocal autonomy; and an increase in the institutional and administrative ability and efficiency of the state, so that respect for the plurality of nonstate local and foreign actors involved in social intervention does not result in the fragmentation and segmentation of the polity.

\section{References}

Aguiar, Chaves de (1891) A administração colonial. Lisboa: Typographia Lisbonense.

Alexander, Jocelyn (1994) "Terra e Autoridade Política no Pós-guerra em Moçambique," 16 Arquivo 5-68.

Ayittey, George B. N. (1991) Indigenous African Institutions. New York: Transnational Press.

Bayart, Jean-François (1993) The State in Africa: The Politics of the Belly. London: Longman. Bragança, Aquino, \& Jacques Depelchin (1986) "Da Idealização da Frelimo à Compreensão da História de Moçambique," 5/6 Estudos Moçambicanos 29-52.

Centro, de Estudos Africanos (1998) O Mineiro Moçambicano. Maputo: Imprensa Universitária.

Chabal, Patrick (1997) "Apocalypse Now? A Post-Colonial Journey into Africa," Inaugural lecture, delivered on 12 March 1997 in King's College, London, http:// www.kcl.ac.uk/depsta/humanities/pobrst/pcpapers.htm (accessed 10 October 2001).

Chanock, Martin (1998) Law, Custom and Social Order: The Colonial Experience in Malawi and Zambia. Portsmouth, NH: Heineman.

Chiba, Masaji (1989) Legal Pluralism: Toward a General Theory Through Japanese Legal Culture. Tokyo: Tokai Univ. Press.

Chichava, José António (1999) Participação Comunitária e Desenvolvimento: o Caso dos Grupos Dinamizadores em Moçambique. Maputo: INLD.

Chingono, Mark (1996) The State, Violence and Development: The Political Economy of War in Mozambique, 1975-1992. Avebury, United Kingdom: Aldershot.

Copans, Jean (1990) La longue marche de la modernité africaine: savoirs, intellectuels, démocratie. Paris: Karthala.

Cuahela, Ambrósio (1996) Autoridade Tradicional em Moçambique. Maputo: Ministério da Administração Estatal.

Darian-Smith, Eve, \& Peter Fitzpatrick, eds. (1999) Laws of the Postcolonial. Ann Arbor: Univ. of Michigan Press.

Dezalay, Yves, \& Bryant Garth, eds. (2002) Global Prescriptions: The Production, Exportation, and Importation of a New Legal Orthodoxy. Ann Arbor: Univ. of Michigan Press.

Dinerman, Alice (1999) 'O Surgimento dos Antigos Régulos como 'Chefes de Produção' na Província de Nampula-1975-1987,” 17 Estudos Moçambicanos 95-246.

Ela, Jean-Marc (1994) Restituer l'histoire aux sociétés africaines. Promouvoir les sciences sociales en Afrique noire. Paris: LHarmattan. 
Ennes, António (1946) Moçambique: relatório apresentado ao governo. Lisboa: Agência Geral das Colónias.

Esteva, Gustavo, \& Prakash Madhu Suri (1998) Grassroots Postmodernism: Remaking the Soil of Cultures. London: Zed Books.

Fisiy, Cyprian, \& Mitzi Goheen (1998) "Power and the Quest for Recognition: NeoTraditional Titles Among the New Elite in Nso', Cameroon," 68 Africa 383-402.

Fitzpatrick, Peter (1983) "Law, Plurality and Underdevelopment," in D. Sugarman, ed., Legality, Ideology and the State. London: Academic Press.

Francisco, António A. S. (2003) "Reestruturação Económica e Desenvolvimento," in B. S. Santos \& J. C. Trindade, eds., Conflito e Transformação Social: uma Paisagem das Justiças em Moçambique. Oporto: Afrontamento.

Gable, Eric (1995) "The Decolonization of Consciousness: Local Skeptics and the "Will Be Modern' in a West African Village," 22 American Ethnologist 242-57.

Galanter, Marc (1981) "Justice in Many Rooms: Courts, Private Ordering and Indigenous Law," $19 \mathrm{~J}$. of Legal Pluralism 1-47.

Geffray, Christian (1990) La cause des armes au Mozambique. Paris: Karthala.

Gentili, Anna Maria (1999) O Leão e o Caçador. Uma História da Africa sub-saariana. Maputo: Arquivo Histórico de Moçambique.

Ghai, Yash (1991) "The Role of Law in the Transition of Societies. The African Experience," $35 \mathrm{~J}$. of African Law 8-20.

Gonçalves Cota, José (1944) Mitologia e direito consuetudinário dos indígenas de Moçambique. Lourenço Marques, Mozambique: Imprensa Nacional.

—_ (1946) Projecto definitivo do Código Penal dos indígenas da Colónia de Moçambique. Lourenço Marques, Mozambique: Imprensa Nacional.

Griffiths, John (1986) "What Is Legal Pluralism?," 24 J. of Legal Pluralism 1-56.

Gundersen, Aase (1992) "Popular Justice in Mozambique. Between the State Law and Folk Law," 1 Social and Legal Studies 257-82.

Hall, Margaret, \& Tom Young (1991) "Recent Constitutional Developments in Mozambique," $35 \mathrm{~J}$. of African Law 102-15.

Honwana, Alcina (2002) Espíritos Vivos, Tradiçôes Modernas. Maputo: Promédia.

Hooker, M. Barry (1975) Legal Pluralism: An Introduction to Colonial and Neo-Colonial Laws. Oxford, United Kingdom: Clarendon Press.

Isaacman, Allen (1990) Régulos, Diferenciação Social e Protesto Rural. Maputo: RIEA.

Khatibi, Abdelkebir (1983) Maghreb pluriel. Paris: Denoël.

Ki-Zerbo, Françoise (1996) "Colonialism and Private Law in Africa," 10 African Environment 55-85.

Klug, Heinz (2000) Constituting Democracy: Law, Globalism and South Africa's Political Reconstruction. New York: Cambridge Univ. Press.

- - (2002) "Comunidade, propriedade e garantias na Africa do Sul rural: oportunidades emancipatorias ou estrategias de sobrevivencia marginalizadas?," in B. S. Santos, ed., Produzir para Viver: Os Caminhos da Producao Nao Capitalista. Rio de Janeiro: Record.

Le Roy, Etienne (1992) "Les fondements anthropologiques des droits de l'homme Crise de l'universalisme et post modernité," 48 Revue de la recherche juridique Droit prospectif, Année XVII.

Lippman, Matthew (1985) "Multinational Corporations and Human Rights," in G. W. Shepherd \& V. P. Nanda, eds., Human Rights and Third World Development. Westport, CT: Greenwood Press.

Lopes, Manoel M. (1909) Subsídios para um código de usos e costumes indígenas nos territórios da Companhia de Moçambique. Beira, Mozambique: Imprensa da Companhia de Moçambique.

Macaulay, Stewart (1983) "Private Government," Disputes Processing Research Program Working Papers No. 6. University of Wisconsin-Madison.

Mamdani, Mahmood (1996) The Citizen and Subject: Contemporary Africa and the Legacy of Late Colonialism. Princeton: Princeton Univ. Press. 
(1999) "Indirect Rule, Civil Society and Ethnicity: The African Dilemma," 23 Social Justice 145-50.

Mappa, Sophia (1998) Pouvoirs traditionnels et pouvoir de l'état en Afrique: l'illusion universaliste. Paris: Karthala.

Mbembe, Achille (2000) "à propos des écritures africaines de soi," 77 Politique Africaine $16-43$.

- (2001) On the Postcoloniality. Berkeley: Univ. of California Press.

Melissaris, Emmanuel (2004) "The More the Merrier? A New Take on Legal Pluralism," 13 Social and Legal Studies 57-79.

Meneses, Maria Paula (2004) "Toward Inter-legality? Traditional Healers and the Law in Post-Colonial Mozambique," 27 Beyond Law 7-31.

Meneses, Maria Paula et al. (2003) "As Autoridades Tradicionais no Contexto do Pluralismo Jurídico," in B. S. Santos \& J. C. Trindade, eds., Conflito e Transformação Social: uma Paisagem das Justiças em Moçambique. Oporto: Afrontamento.

Merry, Sally (1988) "Legal Pluralism," 22 Law E Society Rev. 869-96.

Minter, William (1998) Os Contras do Apartheid. Maputo: Arquivo Histórico de Moçambique.

Moiane, Eugénio (1994) "Consuetudinary and Statutory Land Law and Administration in Mozambique," in R. Weiss \& G. Meyers, eds., Second National Land Conference in Mozambique: Briefing Book. Madison: University of Wisconsin, Land Tenure Center.

Mondlane, Eduardo C. (1969) Struggle for Mozambique. London: Harmondsworth.

Mondlane, Luís A. (1997) "O acesso à justiça e meios alternativos de resolução de conflitos," 2 Revista Jurídica 134-46.

Monteiro, Oscar (1999) "Governance and Decentralization," in B. Ferraz \& B. Munslow, eds., Sustainable Development in Mozambique. Oxford, United Kingdom: James Currey.

Moore, Sally F. (1978) Law as Process: An Anthropological Approach. London: Routledge and Kegan Paul. - (1992) "Treating Law as Knowledge: Telling Colonial Officers What to Say to Africans About Running ‘Their Own' Native Courts,” 26 Law \& Society Rev. 11-46. - (1994) Anthropology and Africa. London: The Univ. Press of Virginia.

Nader, Laura, ed. (1969) Law in Culture and Society. Chicago: Aldine.

(2002) The Life of Law: Anthropological Projects. Berkeley: Univ. of California Press.

Ndegwa, Stephen N. (1997) "Citizenship and Ethnicity: An Examination of Two Transition Moments in Kenyan Politics," 91 American Political Science Rev. 599-616.

Negrão, José (2003) "Sistemas Costumeiros de Terra," in B. S. Santos \& J. C. Trindade, eds., Conflito e Transformação Social: uma Paisagem das Justiças em Moçambique. Oporto: Afrontamento.

Nzouankeu, Jacque Mariel (1997) "Stakes and Perspectives of Decentralization as a Means of Achieving Democracy in Senegal." Paper presented to the International Conference on Traditional Contemporary Forms of Local Participation and SelfGovernment in Africa, Nairobi, October.

O'Laughlin, Bridget (2000) "Class and the Customary: the Ambiguous Legacy of the Indigenato in Mozambique," 99 African Affairs 5-42.

Panikkar, Raimon (1984) "La notion des droits de l'homme est-elle un concept occidental?,” XVII Interculture 3-27.

- (1996) "Qui a peur de perdre son identité l'a déjà perdue?," 2 Le Monde, Avril, p. 13.

Penvenne, Jeanne (1995) African Workers and Colonial Racism. London: James Currey.

Randeria, Shalini (2002) "Pluralismo jurídico, soberania fracturada e direitos de cidadania diferenciais: instituições internacionais, movimentos sociais e o Estado póscolonial na Índia," in B. S. Santos, ed., Reconhecer para libertar. Os caminhos do cosmopolitismo multicultural. Rio de Janeiro: Record. 
Sachs, Albie, \& Gita Honwana Welch (1990) Liberating the Law: Creating Popular Justice in Mozambique. London: Zed Books.

Sánchez, Beatriz E. (2001) "El reto del multiculturalismo jurídico. La justicia de la sociedad mayor y la justicia indígena," in B. S. Santos \& M. García-Villegas, eds., El Caleidoscopio de las Justicias en Colombia, Vol. II. Bogotá: Colciencias-Uniandes-CESUniversidad Nacional-Siglo del Hombre.

Santos, Boaventura de Sousa (1995) Toward a New Common Sense-Law, Science and Politics in the Paradigmatic Transition. New York: Routledge.

—_ (1997) "Por uma concepção multicultural de Direitos Humanos," 48 Revista Crítica de Ciências Sociais 11-32.

—_ (2002) Toward a New Legal Common Sense. London: Butterworths.

Santos, Boaventura de Sousa, \& Trindade João Carlos, eds. (2003) Conflito e Transformação Social: uma Paisagem das Justiças em Moçambique. Oporto: Afrontamento.

Sheth, Dhirubhai L. (1989) "Nation-Building in Multi-Ethnic Societies: The Experience of South Asia," 14 Alternatives 379-88.

Starr, June, \& Collier Jane, eds. (1989) History and Power in the Study of Law. Ithaca: Cornell Univ. Press.

Tamanaha, Brian (1993) "The Folly of the 'Social Scientific' Concept of Legal Pluralism," $20 \mathrm{~J}$. of Law and Society 192-217.

Tate, Neal, \& Torbjörn Vallinder, eds. (1995) The Global Expansion of Judicial Power. New York: New York Univ. Press.

Teubner, Gunther (1992) "The Two Faces of Janus: Rethinking Legal Pluralism," 13 Cardozo Law Rev 1443-62.

Tie, Warwick (1999) Legal Pluralism. Toward a Multicultural Conception of Law. Dartmouth, United Kingdom: Aldershot.

Trindade, João Carlos (2003) "Rupturas e Continuidades nos processos políticos e jurídicos," in B. S. Santos \& J. C. Trindade, eds., Conflito e Transformação Social: uma Paisagem das Justiças em Moçambique. Oporto: Afrontamento.

Twining, William (1999) Globalisation and Legal Theory. London: Butterworths.

Vail, Leroy, \& Landeg White (1980) Capitalism and Colonialism in Mozambique: a Study of Quelimane District. London: Heinemann.

Van, Rouveroy van Nieuwaal Emile Adriaan B., \& Rijk van Dijk, eds. (1999) African Chieftancy in a New Socio-Political Landscape. Leiden: African Studies Center.

von Benda-Beckmann, Franz (1988) "Comment on Merry," 22 Law E Society Rev. 897901.

(1991) "Unterwerfung oder Distanz: Rechtssoziologie, Rechtsanthropologie und Rechtspluralismus aus rechtsanthropologischer Sicht," 12 Zeitschrift für Rechtssoziologie 97-119.

Werbner, Richard (1996) "Introduction: Multiple Identities, Plural Arenas," in R. Werbner \& T. Ranger, eds., Postcolonial Identities in Africa. London: Zed Books.

Williams, J. Michael (2004) "Leading from Behind: Democratic Consolidation and Chieftancy in South Africa," 42 J. of Modern African Studies 113-36.

Williamson, John (2000) "What Should the World Bank Think about the Washington Consensus," 15 The World Bank Observer 251-64.

Young, Crawford (1994) The African Colonial State in Comparative Perspective. London: Yale Univ. Press.

\section{Statutes Cited}

Decree No. 12.533 established the Political, Civil and Criminal Statute of Indigenous Populations of Angola, Mozambique and Guinea (1926).

Decree No.16.473 established the Political, Civil and Criminal Statute of Indigenous Populations of Portuguese colonies in Africa [Estatuto do Indigenato] (1929). 
Decree No. 5.639 attributed to régulos and cabos de terra the statute of status of administrative assistants (1944).

Decree No. 13.128 rewarded the traditional authorities for their participation in the implementation of labor contracts (1950).

Boletim Oficial No. 2469/B/2, Central Division of Indigenous Affairs (June 25, 1952).

Constitution of 1975, the first Mozambican Constitution.

Law 12/78, the first law on the organization of the judicial system after the independence (1978).

Constitution of 1990, the second Mozambican Constitution.

Law 4/92 created the community courts (1992).

Law 10/92, the second law on the organization of the judicial system after the independence (1992).

Law 19/97, the new Land Law (1997).

Decree No. 55/98 regulated the activities of NGOs (October 13, 1998).

Decree No.15/2000 created the local community authorities (2000).

Boaventura de Sousa Santos is Professor of Sociology at the University of Coimbra (Portugal), and ILS Distinguished Legal Scholar at the University of Wisconsin-Madison. He has published widely on globalization, the sociology of law and the state, social movements, interculturality, and epistemology. His recent books in English include Toward a New Legal Common Sense: Law, Globalization, and Emancipation (Butterworths, 2002); Democratizing Democracy: Beyond the Liberal Democratic Canon (editor, Verso, 2006); Law and Counter-hegemonic Globalization (co-editor with Cesar Rodriguez Gavarito, Cambridge University Press, 2005). 
